\title{
KOTA MEDAN MENJADI BRAND IMAGE WISATA SYAR'I
}

\author{
Mospa Darma \\ Fakultas Hukum, Universitas Tjut Nyak Dhien, Program Studi Hukum \\ Email : jhonluckylucky@yahoo.com
}

\begin{abstract}
Halal products are products that can be consumed by all groups, especially Muslims, in the content of halal products in their composition which is believed by Muslims to have guaranteed cleanliness and health, both real and not tangible. Halal products circulating in the community are marked with a halal label from the MUI so that Muslims can clearly distinguish, especially products that can be consumed. The world of tourism cannot be separated from the need for products that are consumed by Muslims so that the prospect of tourism coupled with sharia products makes tourism a place for all people. Even better with sharia products that are in a place that gives rise to sharia culinary tourism. In areas where the majority of non-Muslims are, if halal products are created, it will provide great opportunities for the business world. In terms of foreign exchange sources from tourism, the opportunity for halal products is very large both in the tourism sector such as in Bali, Bunaken, Lake Toba and areas where all the needs of the community are sharia products and sharia tourism.
\end{abstract}

Keywords: Halal Products, Brand Image, Syar'i Travel.

\begin{abstract}
Abstrak
Produk halal adalah merupakan produk yang bisa dikonsumsi bagi seluruh umat khususnya bagi umat Islam, dalam kandungan produk halal dalam komposisinya yang diyakini secara umat Islam sudah menjamin akan kebersihan serta kesehatan baik secara nyata maupun tidak secara nyata. Produk halal yang beredar dimasyarakat ditandai dengan adanya lebel halal produk dari Majelis Ulama Islam sehingga dapat dengan jelas Umat Islam khususnya membedakan produk-produk yang bisa dikonsumsinya. Dunia pariwisata tak terlepas dari kebutuhan produk-produk yang dikonsumsi oleh umat Islam sehingga prospek pariwisata dengan dibarengi produk-produk secara syariah membuat sebuah pariwisata tersebut menjadi tempat bagi seluruh kalangan bahkan sebaiknya dengan produk-produk syariah yang berada disuatu tempat sehingga memunculkan pariwisata kuliner secara syariah.Pada suatu wilayah yang mayoritasnya non Muslim jika diciptakan produk-produk halal akan memberikan peluang yang besar bagi dunia bisnis.Dalam merebaknya prospek sumber devisa dari wisata, peluang yang sangat besar pada produk halal baik di wisata seperti di Bali, Bunaken, danau Toba maupun suatu daerah yang dari segala kebutuhan masyarakatnya secara produk syariah maupun pariwisata secara syariah.
\end{abstract}

Kata kunci:Produk Halal, Menjadikan Prospek, Wisata Kuliner.

\section{Pendahuluan}

Dalam pandangannya perbuatan

pribadi konsumen merupakan perbuatan

perbuatan perseorangan yang berperan serta

secara langsung pada kegiatan memperoleh, menggunakan serta menentukan produk dan

jasa atas konsumen menurut pandangan

Tjiptono (2008), termasuk proses pengambilan keputusan yang mendahului dan mengikuti akan tindakan-tindakan tersebut yang menurut Hasan (2009), dalam mendapatkan serta memperoleh suatu produk juga melakukan kembali dan dalam mengambil keputusan, sebagai perilaku konsumen secara khusus adalah merupakan respon psikologis yang kompleks. Menurut Kotler dan Keller (2006) mdiungkapkannya 
Vol. 2 No. 2 Bulan Oktober 2021 - Maret 2022

"kepuasan konsumen merupakan kunci utama untuk mempertahankan konsumen".

Apabila produk yang dikonsumsi masuk kedalam tubuh maka akan menjadi mendarah daging hingga anak keturunan. Halal-haramnya makanan dapat menjadi penentu bagi peradaban umat manusia kedepannya yang berkaitan akan keturunan dan generasi penerus kelak, mengacu pada sifat halal dan haram tersebut benda-benda yang diolah seperti makanan dan minuman, kosmetik serta obat-obatan digolongkan ke dalam musy-tabihat (syubahat), meskipun bahan utama produksi termasuk halal terlebih lagidikhawatirkan produk yang asal mulanya dari negara yang bermayoritaskan non muslim.

Produk halal yang beredar dimasyarakat secara volume yang besar dan menyeluruh menjadikan satu peluang usaha bisnis kuliner dalam bidang wisata, bahwa wisata kuliner secara syar'i memancing para turis baik lokal maupun secara non lokal untuk datang mencicipi cita rasa produk pangan ataupun minuman bahkan produk yang menempel dan masuk kedalam tubuh merupakan tern wisata yang unik dari tempat-tempat lainnya. Oleh karenanya peneliti memnbahas seputar bagimanakah dampak dari terciptanya wisata halal dan syariah di kota Medan

\section{Tinjauan Pustaka}

Pengertian pasar sesuai kamus Umum Bahasa Indonesia yaitu: Lokasi yang disediakan untuk jual beli, akhir pekan, oleh kelompok dan lain sebagainya mempunyai tujuan untuk memenuhi kebutuhan hidup. Pasar pandangan Mankiw (2007) yaitu kumpulan konsumen dan penjual barang/ jasa khusus. Menurut Zayinul Fata (2010), penawaran produk ditentukan oleh pembeli. Menurut Kotler \& Armstrong (1999), pasar merupakan sekelompok pembeli aktual dan potensial dari suatu produk atau jasa. Kondisi suatu pasar tergantung pada kebutuhan orang dalam jual beli. Penjual mempunyai peran sebagai industri dan pembeli sebagai pasar dalam pandangan pemasar, penjual memberikan produk dan jasa sebagi yang dihasilakan serta memberitahu kan dan mendistribusikan ke pasar imbalannya, mendapatkan uang dan keterangan dari pasar.

Pasar sesuai Kotler, 2002 yaitu tempat fisik antar pembeli dan penjual bertemu dlam jual beli jasa dan barang. Pengertian pasar sesuai W.Y. Stanton dimana suatu wadah dengan tujuan merencanakan, menetapkan, mempublikasikan serta mengalokasikan barang dan jasa, kepuasan pembeli diutamakan. Pengertian pasar sesuai William J. Stanton, yaitu tempat adanya sekelompok orang yang ingin membelanja 


\section{Vol. 2 No. 2 Bulan Oktober 2021 - Maret 2022}

kan uangnya, atau dapat dikatakan pasar merupakan tempat berlangsungnya transaksi jual-beli menggunakan uang sebagai alat tukar. Pengertian pasar sesuai Philip \& Duncana dan Pendapat ini didukung pada tahun 1005 oleh Philip \& Duncanadan yang mendefinisikan pasar sebagai sesuatu yang digunakan untuk menempatkan barangbarang yang konsumen butuhkan. Pendapat yang dikemukakan oleh W. Y. Stanton dan Phillips \& Duncan dipercaya bahwa tempat untuk menempatkan barang yang akan dibeli oleh konsumen merupakan pasar.

Pengertian pasar sesuai Menurut $\mathrm{H}$. Nystrom yaitu sebuah lokasi khusus yang digunakan sebagai wadah terjadinya kegiatan pendistribusian baik barang maupun jasa dari produsen terhadap konsumen. dan pasar yaitu lokasi pertukaran barang dan jasa penjual dan pembeli.Pengertian pasar sesuai Handri Ma'aruf "2005" yaitu pasar mempunyai 3 pengertian, yaitu:

1) Pasar pada definisi "tempat" yaitu lokasi berkumpulnya produsen dengan konsumen.

2) Pasar pada definisi "hubungan ermintaan dan penawaran" merupakan transaksi jual-beli yang terjadi di lokasi peristiwa.

3) Pasar pada definisi "sejumlah anggota masyarakat memiliki keperluan dan kemampuan membeli”, hal ini berpedoman atas 2 hal, yaitu kepentingan dan kemampuan beli. Jadi, pasar merupakan sekumpulan masyarakat yang mampu membeli suatu benda atau jasa untuk kebutuhan mereka.

Pengertian pasar sesuai Asosiasi Pemasaran Amerika Serikat merupakan lokasi dalam aktivitas usaha perniagaan lalu diarahkan khusus dari produsen/penjual ke konsumen/pembeli untuk barang dan jasa. Solusi pasar yang mempunyai produk halal dari semua konsumen yang sehat higienis.

Menurut Kotler \& Armstrong (2008: 177), keputusan pembelian konsumen tak lepas dari tahapan. Dari tahapan tersebut, pemahaman terhadap masalah yang akan dihadapi sampai kegiatan transaksi pembelian dan keputusan oleh konsumen merupakan suatu tahapan proses secara jelas produk yang dibeli oleh konsumen. Sesuai Olson (dalam Sangadji, 2013:332) menyatakan bahwa keputusan pembelian merupakan proses solusi masalah yang berupa menganalisis keentingan dan kemauan, pemeriksaan informasi, penilaian sumber pemilihan alternatif pembelian serta keputusan pembelian dan integritas pasca pembelian

Sejak awal munculnya kerajaan ataupun permukiman di Indonesia khususnya daerah perkotaan telah tumbuh pasar tradisional. Santoso (2008) menyatakan 


\section{Vol. 2 No. 2 Bulan Oktober 2021 - Maret 2022}

bahwa pada abad ke-14 Kerajaan Majapahit, persimpangan jalan yang terletak di dalam lingkungan pusat kota sudah mempunyai pasar. Eerste (dalam Adrisijanti:2000) menyatakan bahwa pada tahun 1646, Banten memiliki 3 pasar tradisional, yakni Paseban, Pecinan, dan Karangantu.

Peristiwa dimana konsumen yakin untuk membeli produk merupakan istilah lain dari keputusan pembelian konsumen menurut Kotler \& Armstrong (2008:177). Bagaimana konsumen melewati tahapan, berkaitan erat dengan keputusan pembelian konsumen, yaitu mengetahui permasalahan yang akan dihadapi konsumen terhadap kegiatan transaksi pembelian dan keputusan pembelian. Keputusan pembelian menurut pendapat Olson dalam Sangadji (2013:332) merupakan pemecahan masalah yang dapat diproses melalui analisis atau mengetahui kepentingan dan kemauan, pemeriksaan informasi, penilaian sumber pemilihan alternatif pembelian serta keputusan pembelian dan integritas pasca pembelian.

Menurut Barry J. Babin (2014:133) ada 3 indikator Word Of Mouth, yaitu: 1. Kesediaan konsumen untuk menyampaikan hal yang positif mengenai mutu layanan dan produk kepada masyarakat. 2. Memberikan rekomendasi layanan dan produk perusahaan kepada masyarakat. 3. Mendorong relasi untuk bertransaksi melakukan kegiatan pembelian produk maupun jasa perusahaan.

Keputusan dalam menentukan suatu tindakan dari sejumlah alternatif dalam konteks pembelian produk/jasa yang akan digunakan merupakan definisi lain dari keputusan pembelian menurut pandangan Hasan (2013:181). Setiap muslim wajib makan makanan halal. Islam telah mengatur dalam QS. Al-Ma'idah ayat 88 tentang bagaimana cara memenuhi kebutuhan makanan/pangan dimana manusia harus mengonsumsi makanan yang halal. Ciri yang sangat penting untuk membedakan makanan halal dengan yang haram adalah label halalnya. Hal ini dapat membantu konsumen muslim membandingkan dan membuktikan mutu produk produk yang mana Indonesia memiliki mayoritas muslim yang sangat besar.

\section{Metode Penelitian}

Metode penelitian ini menggunakan pendekatan normatif sebagai perspektif komersial dan landasan hukum yang baik dimana hukum positif dan hukum Islam ada.

\section{Hasil Penelitian dan Pembahasan}


Aktivitas jual beli yang terjadi di pasar antara pedagang dan pembeli dapat menimbulkan umpan balik secara langsung karena pedagang mengetahui reaksi pembeli dan segera memberikan umpan balik kepada pembeli. Kejadian ini sesuai dengan teori Rohim (2009:16) bahwa pedagang dan pembeli sama-sama menerima umpan balik (verbal/non-verbal) dengan sengaja atau tidak sengaja yang bertujuan untuk mengetahui jika permintaan yang diberitahukan diterima dengan baik atau tidak. Seiring dengan terjadinya perubahan perekonomian dan globalisasi, telah terjadi perubahan dalam perilaku berbelanja pada masyarakat.

Workshop Percepatan Pengemba ngan yang telah dilakukan oleh Kementerian Pariwisata bertujuan agar the world's best halal tourist destination disematkan kepada Indonesia. Event ini diadakan untuk memberikan layanan makan dan minum yang telah memiliki sertifikasi halal. Dari 116 negara dan 1,8 juta voters, Indonesia sukses menjadi pemenang sejak 2016. Padahal, biasanya Malaysia dan Turki yang meraih kemenangan.

Promosi maksimal Kemenpar melalui seluruh siaran medianya, Indonesia dinobatkan sebagai pemenang utama pada tahun 2016, diantaranya pada kategori
World's Best Airline for Halal Travellers, World's Best Airport for Halal Travellers, World's Best Halal Cultural Destination, World's Best Family Friendly Hotel, World's Most Luxurious Family Friendly Hotel, World's Best Halal Beach, World's Best Halal, World's Best Halal Honeymoon Destination, World's Best Halal Tour Operator-Ero Tour, World's Best Halal Destination, World's Best Halal Culinary Destination, dan World's Best Hajj \& Umrah Operator.

Dalam strategi promosi Kemenpar, penghargaan tersebut merupakan branding. Bukti penghargaan berarti telah diCalibration menggunakan standar global, secara internal juga telah meningkatkan Confidence, dan secara eksternal memperkuat Credibility atau sering disebut juga dengan istilah 3C oleh Menpar Arief Yahya. Hal ini berdampak kepada 2 juta wisman yang pergi ke NTB pada tahun 2015. Kemudian pada tahun 2016 meningkat sebanyak 2,4 juta wisman dan tahun 2017 terjadi lagi peningkatan sebanyak 2,7 juta wisman.

Dalam kasus Pariwisata Halal Dunia yang menjadi penilai yaitu Global Muslim Travel Index (GMTI) yang telah diapresiasi oleh Mastercard-Crescent Rating. Indonesia dinyatakan sebagai juara bersama Malaysia 


\section{Vol. 2 No. 2 Bulan Oktober 2021 - Maret 2022}

pada April 2019. Tahun sebelumnya berada di peringkat kedua dan 2 tahun sebelumnya berada di peringkat nomor 3. Sejauh ini menurut GMTI Indonesia terus mengalami peningkatan. MUI juga telah menerbitkan sebanyak 767 sertifikat halal untuk Kota Medan khususnya produk makanan dan minuman.

Pada saat ini produk halal telah masuk dalam bisnis dan perdagangan (Borzooei and Asgari 2013). Tetapi bukan menjadi hal biasa, dengan mencari, menyoroti dan mengkomunikasikanHalal dapat menjadi faktor pembeda.Menurut"Rajagopal et al2011" mungkin dapat memperluas ke pasar dunia dengan serttifikasi halal .Sementara ini semakin banyak negara telah mengadopsi Islamic Finance dalam sistem perbankan mereka(Ahmad 2014)Perdagangan makanan halal telah meningkat pesat. Aziz dan Chok (2013) kehalalan produk mempengaruhi perilaku konsumen yang ingin membeli produk. Sebaliknya, akan ditinggalkan oleh konsumennya jika perusahaan yang mengacuhkan isu halal ini.

Di dalam dunia bisnis, terdapat komoditas yang terbentuk dari sumber daya khususnya bagi wisata. Hal ini mempunyai pengaruh terhadap segala peluang usaha yang diperhatikan secara mendetail. Pariwisata dapat menjadi kebutuhan manusia secara tersier dan juga primer terutama untuk golongan tertentu. Pariwisata secara primer adalah solusi untuk kepentingan manusia secara jasmani maupun rohani.

Pangsa pasar produk halal mencapai 2 miliar konsumen muslim di seluruh dunia yang membutuhkan produk halal. Terjadi peningkatan sebanyak 20\%-30\% per tahun untuk \$600 miliar AS yang memiliki potensi produk halal global.

Berikut di bawah ini beberapa marketing strategy yang tepat dan efesien untuk memulai startup:

\section{Merencanakan Program Referral}

Peningkatan traksi startup dapat menggunakan strategi ini sebagai langkah yang tepat. Rekomendasi lebih dari 90\% orang sangat dipercaya dibandingkan perusahaan yang menjual produk melalui pendekatan sederhana.

Bukan sesuatu ntang ganpang membangun program referal dari nol. Sebagi penolong percepatan eksekusi, perusahaan pihak ketiga yang fokus di bidang tersebut secara khusus dapat menarik tools sehingga konsentrasi berfokus pada penciptaan dan pemasaran produk.

\section{Konten pemasaran}

Merupakan salah satu langkah mudah konten pemasaran saat ini yang secara nyata 


\section{Vol. 2 No. 2 Bulan Oktober 2021 - Maret 2022}

sampai konsumen lebih banyak, harus dipastikan pada saat produk sudah siap dipasarkan, konten pemasaran harus dibuat secara masif masif dan edukatif. Tentukan seberapa efektif pemasaran konten untuk produk dan pasar yang akan ditangani.

Secara urgen pilihan masuk (optin) atau pilihan untuk keluar (opt-out) musti selalu ada pada situs atau konten pemasaran dan email yang disebarkan. Menjaga kenyamanan agar tidak membenci produk akibat tidak lengkapnya kedua pilihan. Membuat strategi yang tepat dan smart ketika melancarkan aktivitas mengakuisisi pelanggan secara email dan konten pemasaran.

\section{Kegiatan offline (komunitas)}

Sudah banyak komunitas yang secara khusus bisa dituju sesuai dengan penawaran produk, maka dengan mencoba mengadakan atau mengikuti bermavam aktivitas offline yang tersedia. Mayoritas konsumen potensial, investor partner sampai karyawan yang suka dengan quality time dalam berkumpul di setiap iven.

Merk produk harus sudah tampil pada acara tersebut, keberhasilan 10 konsumen diperoleh setidaknya nilai tambah yang dapat diraih selain secara testimoni atau komentar pada situs.

\section{Kompetisi online}

Melalui media sosial menggelar kompetisi atau kontes juga merupakan strategi marketing yang efektif sebagi startup yang dapat dilaksanakan berkelanjutan. Strategi ini dapat memperoleh pelanggan lebih banyak, meningkatkan brand awareness serta mempromosikan produk secar pemberian hadiah/produk yang dipasarkan. Sangat diselegasikan untuk semua startup melakukan aktivitas secara rutin, yang menghasilkan kesuksesan dan bisa meningkatkan volune konsumen yang lebih banyak.

\section{Konten Marketing}

Pentingnya konsistensi strategi marketing serta dedikasi pemasar dalam startup ini menghasilkan konten kebutuhan pelanggan secara khusus, tidak hanyas menjual. Dibandingkan dengan iklan banner maupun televisi, konten yang dapat menimbulkan kepercayaan, ketergantungan serta kedekatan menjadi penghubung bagi perusahaan terhadap kebutuhan konsumen. Ketika ketiga unsur tersebut sudah terlaksana dengan baik, konsumen menjadi mudah untuk mengambil keputusan dalam pembelian.

\section{Ekslusif Beta}

Melalui strategi ini, kita dapat membuat rancangan tahapan sebelum 
diluncurkannya startup menggunakan pemanfaatan sifat alamiah manusia yang mengarah terhadap keinginan yang tidak bisa tercapai. Contohnya yakni, sistem undangan eksklusif yang diterapkan terhadap masyarakat tertentu dengan memanfaatkan first in get first scheme (memprioritaskan pendaftar yang lebih dulu). Pada saat debut pertama kali ke publik, PayPal dan Pinterest berhasil mengadopsi strategi first in get first.

\section{Mengikuti Pameran (Event) yang Tepat}

Sebagai perusahaan pemula, tidak perlu gentar untuk keluar dan mengikuti pameran offline yang sejalan dengan industri startup perusahaan.

\section{Fokus}

Untuk startup dipilih pasar yang paling tepat, jangan berupaya meraih segala orang yang nantinya mengacaukan dari hal terkecil, lantas kembangkan pasrar ketika sudah siap. Contihnya ketika Facebook awalnya hanya pasar mahasiswa pada kampus tertentu, saat ini sudah merupakan segala pasar.

\section{Membangun Image Sebagai Branding}

Dimulai oleh tim yang kecil kebanyakan startup yang sukses hanya dilakukan oleh 1 founder. Kunci terpenting ketika memulai startup ketika mempunyai keterbatasan tim, yaitu sebagai pemain utama yang terlibat, tidak boleh merasa canggung. Jika startup diwakili dengan baik, positive energy akan mempengaruhi merk yang positif terhadap startup.

Saat startup-nya masih seumur jagung, Adam D'angelo yang merupakan founder Quore merupakan pengguna yang sangat aktif memberikan jawaban terhadap pengguna lain.

\section{Menggelar Kontes}

Strategi yang mampu mendapatkan traffic sekaligus branding dalam jumlah banyak dan dalam waktu singkat. Jenis kontes yang dapat dipertimbangkan adalah kontes blog/artikel, kontes SEO atau pengguna media sosial yang terlibat dalam kontes.

\section{Bakar Uang}

Membakar uang tidak ilegal dan tidak dilarang oleh hukum. Umumnya, pembakaran uang oleh perusahaan untuk membayar tempat iklan dengan tujuan menghasilkan konsumen dari kampanye. Umpan balik yang didapat juga tidak seperti yang diharapkan. Dengan memberikan uang ini dan menghadiahkan bonus nominal tertentu saat mendaftarkan pengguna di akun layanan perusahaan langsung ke konsumen, jaminan yang diperoleh akan lebih pasti.

Strategi ini berhasil dilakukan oleh PayPal yang memberi tawaran $\$ 10$ pada 
setiap customer baru dan menambahkan ekstra \$10 untuk setiap referral. Penawaran cashback juga kerap dilakukan dengan jumlah tertentu untuk kegiatan transaksi di merchant tertentu.

\section{Merangkul Brand Lain}

Jika Anda ingin memulai sebuah startup dan tidak memiliki modal yang besar, ajaklah startup lain yang sudah stabil. Contohnya seperti kerjasama antara Google dan KitKat yang berhasil memperkenalkan Android 4.4 ke publik menggunakan branding Android dan sebaliknya.

\section{Media Sosial}

Media sosial adalah tempat untuk menghubungkan pelanggan dan calon pelanggan secara efisien. Data yang diambil dari We are Social (Okezone) sebanyak 130 juta dari 265,4 juta penduduk Indonesia yang berperan aktif dalam penggunaan media sosial, sedangkan penetrasi pengguna internet sebanyak 132,7 juta.

\section{Re-marketing}

Strategi ini berfungsi dalam peningkatan awareness, traffic serta penjualan. Ini mirip dengan Situs Digital Marketing Agency Hero Soft yang merupakan fitur lanjutan di Google AdWords, terutama untuk Google Display Network. Fitur ini akan menayangkan iklan Google AdWords kepada pengguna yang telah mengunjungi situs tersebut dan menyebabkan peningkatan konversi penjualan.

Memasang instalasi Facebook custom audience pixel juga merupakan cara yang efektif untuk digunakan dalam strategi marketing. Hal ini bertujuan agar dapat menargetkan konsumen yang sudah mengenal produk yang telah dipasarkan melalui iklan di Facebook. Cukup dengan meng-upload daftar e-mail dan nomor ponsel minimal 20 orang, custom audience akan mengirimkan iklan secara otomatis. Cara ini dapat mengumpulkan konsumen lebih cepat dengan menggunakan jumlah pengunjung yang melihat situs web dan mobile application.

\section{Search Engine Optimization (SEO)}

Strategi ini berfungsi untuk memastikan bahwa konten yang diciptakan memiliki rating yang baik ketika dicari di mesin pencari melalui keywords tertentu sesuai dengan masalah yang dihadapi pengguna.

\section{Pendekatan Konten "Customer Journey"}

Strategi ini merupakan perjalanan digital konsumen yang memperhatikan bagaimana pemasar bisa mendapatkan konten yang relevan di setiap saluran sehingga ketika konsumen hadir di saluran 
tertentu, konsumen akan mendapatkan informasi yang tepat, baik secara substansi maupun waktu.

\section{Tidak Memaksakan Konten Promosi}

Penjualan (hard selling) merupakan salah satu stigma negatif di ruang konsumen digital. Untuk mengatasi ini dibutuhkan pemasaran menggunakan konten marketing yang kreatif.

\section{Email Marketing}

Strategi ini merupakan cara yang bersifat sangat personal untuk menjalin hubungan dengan calon konsumen. Rancangan untuk mendatangkan lead diperlukan untuk membangun calon konsumen yang potensial dan loyal. Penentuan keberhasilan e-mail marketing sangat bergantung kepada etika. Jangan pernah mengirimkan e-mail penawaran ke alamat $e$-mail konsumen yang tidak bersedia mendaftarkan diri.

\section{Inbound Marketing}

Strategi ini efektif dan tahan lama terhadap pelanggan potensial tetapi penerapannya membutuhkan pengorbanan, konsistensi, dan waktu agar dapat membangun hubungan yang berkualitas.

Melalui iklan di televisi atau kampanye iklan PPC, dapat dilakukan dengan membuat e-mail listing. Metode yang digunakan lebih high-tech, seperti mempublikasikan konten melalui blog/media secara gratis dan membentuk kesan dan eksistensi yang memiliki pengaruh kuat di media sosial.

\section{Influencer marketing}

Strategi ini disebut juga sebagai endorse, yaitu pemasar memilah sekumpulan orang yang populer dan berpengaruh untuk membantu dalam memperkenalkan startupnya. Strategi ini masih tergolong efektif tetapi banyak pengguna mulai berpikir dan menyadari mengenai saran dari influencer murni sebagai afirmasi atau berdasarkan pesanan.

\section{Podcast Marketing}

Disampaikan melalui sisi visual ketika blogging berfokus pada konten, lebih fokus pada sisi audio sehingga Podcast menjadi pelengkap karena media ini. Untuk mengkomunikasikan produk mereka dalam konteks pemasaran, penggunaan Podcast mulai digunakan oleh pemilik startup dan pemasar. Membantu membentuk citra perusahaan memberikan podcast yang bermanfaat dan informatif yang dapat berguna untuk menumbuhkan kesadaran merek.

Haram (Arab: الحرام) dalam pandangan fiqih Islam, haram adalah larangan yang harus dijauhi. Makna Haram dalam Islam adalah perbuatan yang 
Vol. 2 No. 2 Bulan Oktober 2021 - Maret 2022

diharamkan untuk dilakukan dan masyarakat harus menjauhinya. Jika perbuatan haram dilakukan oleh Mukallaf maka disebut maksiat. Secara terminologi, maslahah didefinisikan sebagai penarikan maslahah tetapi menolak mafsadat. Al-Khawarizmi mengungkapkan bahwa maslahah adalah menjaga niat syari'at dengan mencegah perbuatan buruk yang akan menimpa umat.

Haram dibagi menjadi 2 bagian, yaitu:

Haram berdasarkan pembukaan taklif:

1. Haram Mutlak adalah amalan yang larangannya tidak terikat ketentuanketentuan khusus.

2. Haram Muqayyad adalah amalan yang larangannya dikarenakan faktor khusus dan ketidakpunyaan akan sesuatu.

Haram yang dibagi menurut syariat:

1. Haram Munajjaz adalah amalan yang larangannya tidak terikat hal lain.

2. Haram Mu'allaq adalah amalan yang larangannya terikat pada hal lain seperti masuknya waktu tertentu.

Haram AnalysisCritical Control Point (HrACCP)disusun dengan cara-cara.

1. Benda haram serta najis ditetapkan dan diakses.

2. Titik kendali kontrol ditentukan.

3. Tahapan pemantauandibuat.

4. Untuk mengkoreksiadakan tindakan.

5. Sistem pencatatandiadakan.
6. Prosedur verifikasiPenentuandibuat. Makanan dan minuman yang halal mencakup beberapa hal, yaitu:

1. Produk halal yang terdapat pada tubuh.

2. Makanan atau minuman yang halal jenisnya, rasanya maupun bahannya.

3. Diperoleh dengan halal.

4. Minum alkohol. Nabi Muhammad SAW Dulu, masyarakat Arab juga memiliki tradisi mabuk-mabukan yang secara perlahan dimusnahkan oleh Nabi SAW. Pertama pengertiannya yaitu, selagi masih mabuk dilarang melaksanakan shalat (Q.S. An-Nisa:34). Berikutnya menyatakan bahwa lebih besar dari manfaatnya atau kebaikannya khamar atau minuman keras itu dosanya atau keburukannya (Q.S. Al-Baqarah:219). Kemudian aturan yang tegas, oleh karena itu dijauhi sama sekali yang membuktikan bahwa minuman keras/khamr merupakan perbuatan tercela sebagaimana perbuatan setan, (Q.S. Al Maidah:90).

5. Makanan halal yang diproses secara tidak halal, yaitu:

a. Pemotongan dilaksanakan oleh yang bukan beragama Islam menggunakan parang/pisau yang tumpul tanpa menyebut nama Allah. 
Vol. 2 No. 2 Bulan Oktober 2021 - Maret 2022

b. Pemotongan yang bukan untuk penyembelihan musyrik dan darah hewan harus dikuras secara menyeluruh dan dipotong leher dan saluran pernafasannya, menggunakan cara yang sopan dan tidak terkontaminasi bahan utama, rempahrempah atau campuran terlarang lainnya. dan tempat serta alat yang terkontaminasi tidak halal.

Islam memiliki 4 aturan konsumsi Halal, yaitu: 1) Halal seluruhnya tanpa terkecuali, 2) Membawa manfaat besar dibandingkan kerugiannya, 3) Tidak berlebih-lebihan, dan 4) Tidak terbuangbuang. Atas dasar larangannya, haram dibagi menjadi 5, yaitu:

1. Haram Nafsi merupakan amalan yang dilarang bukan karena amalan haram lainnya yang telah mendahului.

2. Haram Ghairi adalah amalan yang larangannya membuka praktik haram lainnya.

3. Imam al Ghazali dalam hal keterbatasan dan esensi, untuk ditinggalkan melalui tuntutan secara pasti dan mengikat dan merumuskan haram dengan sesuatu yang dituntut syari' (Allah SWT dan RasulNya). Bagi pelaku dosa nya pelakunya merupakan yang tercela itu dengan kalimat dalam sifat bentuknya, Imam al Baidhawi, tokoh ushul fiqh Madzhab
Syafi'i, memberikan pandangannya. Ini adalah kebalikan dari anggapan bahwa wajib bagi orang yang meninggalkannya untuk dipuji.

4. Dalam ushul fikih Istilah yang serupa dan bermakna dengan haram adalah AlMahzur (yang dihindari), Al-Ma'siyah (kemaksiatan), Az-Zanb (dosa), AlMamnu (yang dilarang), Al-Qabih (buruk/jelek), As-Sai'ah (jelek), AlFahisyah (keji), Al-Ism (dosa) dan AlMazjur'anh (yang dicegah darinya).

5. Bagi mazhab Hanafi, dalil yang menunjukkan hukum haram harus memiliki kualitas qat'i (tertentu). Jika argumen tersebut memiliki kualitas zanni (relatif), maka argumen tersebut dinyatakan makruh tahrim. Dalam pandangan mayoritas ulama 1 tersebut, jika menjurus pada sifat haram secara dalilnya qat'i maupun zanni.

Q.S. Al-Baqarah [2]:168, Al-Sa'd menjelaskan bahwa ayat ini adalah seruan kepada seluruh umat manusia untuk memakan makanan halal dan menjauhi makanan haram.

Dalam pandangan Muhammad 'Ali al-Shab dimana pada umumnya dengan niat yang sama ia menjadi khitab, agar semua manusia menjadikan produk halal untuk dikonsumsi dalam kehidupan. 
Vol. 2 No. 2 Bulan Oktober 2021 - Maret 2022

\section{Rasulullah SAW bersabda}

"Sesungguhnya yang halal dan yang haram itu jelas. Terdapat diantara keduanya ada pertanyaan keragu-raguan dan umumnya manusia tidak mengetahuinya. Oleh karena itu, barangsiapa yang memelihara taqwa dari syubhat, berarti dia telah membebaskan agama dan kehormatannya, terlarang, seolaholah seseorang menggembalakan ternaknya di sekitar Hima. Ketahuilah bahwa sesungguhnya setiap raja memiliki hima dan ketahuilah bahwa hima Allah adalah larangan-Nya.” (Hr. Muslim).

Menurut Hujjah al-Islâm Muhammad ibn AbûHâmid al-Ghazâlî (w. 550H), yang buruk atau kotor itu dilarang, tapi kadarnya berbeda tiap jenis. Dalam menyikapi halal menurut Imam Al-Ghazali,, orang-orang mukmin membutuhkan kebijaksanaan dalam menyikapinya. Tingkat ketakwaan seseorang dapat dilihat dari produknya, baik makanan maupun minumannya.

Banyaknya mayoritas muslim di Indonesia menyebabkan konsumen muslim harus mendapatkan perlindungan barang dan jasa baik makanan maupun obat-obatan sesuai dengan syariah. Di sisi perlindungan produk halal, LPPOM MUI didirikan pada 6 Januari 1989 yang berfungsi untuk melindungi konsumen Muslim terhadap produk halal (makanan, minuman, obat- obatan dan kosmetik). The World Halal Council (WHC) yang didirikan pada tahun 1999 di Jakarta merupakan inisiatif dari sejumlah negara dan Indonesia di dalamnya. Lembaga ini bertanggung jawab sebagai federasi lembaga sertifikasi halal di seluruh dunia setelah mendapatkan izin internasional. Sekitar $20 \%$ produk makanan dan minuman yang telah memperoleh sertifikasi halal dari LPPOM MUI tersebar di seluruh Indonesia menurut Lukman Hakim (Direktur Eksekutif LPPOM MUI).

Hukum Nasional

Resolusi Majelis Umum PBB N.A/RES/39/248 Tahun 1985 tentang Pedoman Perlindungan Konsumen dan dasar hukum sertifikasi mempunyai 4 poin, yaitu:

1. UU No. 7 Tahun 1996 tentang Pangan

2. UU No. 8 Tahun 1999 tentang Perlindungan Konsumen

3. Keputusan Menteri Kesehatan RI 924/Menkes/SK/VIII/1996 tentang Perubahan Atas Keputusan Menkes RI No.82/Menkes/SK/I /1996 tentang Pecantuman Tulisan Halal pada Label Makanan

4. UU RI No. 33 tahun 2014 tentang Jaminan Produk Halal

Peraturan Menkes Republik Indonesia Nomor 280/Menkes/Per/XI/1976 tentang 


\section{Vol. 2 No. 2 Bulan Oktober 2021 - Maret 2022}

Ketentuan Peredaran dan Penandaan Pangan Yang Memiliki Kandungan Bahan Asal Babi:

Pasal 2:

1) Wadah pembungkus makanan yang diproduksi di dalam negeri atau luar negeri yang mengandung bahan asal babi harus mencantumkan tanda peringatan.

2) Pada ayat 518, tanda peringatan harus berupa gambar babi dan tulisan yang berbunyi "Berisi Babi". Ditulis dengan huruf kapital merah, minimal ukuran Universal Medium Corp 12 dengan garis persegi merah.

3) Peraturan Menteri Kesehatan RI Nomor 76/Menkes/Per/III/78 tentang Label dan Iklan Pangan Pasal 2 berisikan bahwa Kalimat, kata, lambang, logo, gambar, dan lain-lain yang tercantum pada Label harus dalam sesuai dengan asal, sifat, komposisi, mutu serta penggunaan makanan.

4) Surat Keputusan Bersama Menag dan Menkes No. 427/Menkes/SKB/8/1985 dan No. 68 Tahun 1985 tentang Pencantuman Tulisan Halal pada Label Pangan.

Pasal 1 berbunyi "Tulisan halal adalah tulisan yang terdapat pada label yang menjamin kehalalan pangan bagi pemeluk agama Islam.
Pasal 2 Pasal 2 berbunyi "Pencantuman tulisan halal pada label pangan di produk merupakan tanggung jawab produsen yang menjamin kehalalan untuk pemeluk agama Islam.

Pasal 4 berbunyi:

1) Tim Penilai Pendaftaran Pangan Kemenkes RI cq. Dirjen Pengawasan Obat dan Makanan melakukan pengawasan preventif terhadap ketentuan pasal 2 keputusan bersama.

2) Dalam tim penilai pendaftaran pangan sebagaimana tertera pada ayat (1), pasal ini dimasukkan unsur Kemenag RI.

3) Kemenkes RI melakukan pengawasan lapangan terhadap pelaksanaan ketentuan Pasal 2 Keputusan Bersama.

4) Undang-Undang Nomor 23 Tahun 1992 tentang Kesehatan pasal (214) ayat (2) menjelaskan butir (d) ketentuan lain, misalnya makanan dan minuman yang diproduksi dan diolah berdasarkan kebutuhan pangan telah dijamin dengan pencantuman tanda halal.

5) UU No. 7 Tahun 1996 tentang Pangan, pasal (34) ayat (1) mempunyai isi, seseorang yang menyatakan jika label atau iklan yang diperjualbelikan berdasarkan persyaratan agama, maka mereka memiliki tanggung jawab akan 
Vol. 2 No. 2 Bulan Oktober 2021 - Maret 2022

kebenaran pernyataan berdasarkan syarat tersebut.

UU No. 33 Tahun 2014 tentang Jaminan Produk Halal, Pasal (4) menyatakan: Produk yang masuk, beredar serta diperdagangkan di Indonesia wajib memiliki sertifikat halal. Pasal 5 (1), JPH wajib diselenggarakan oleh pemerintah.

Pelabelan halal mencakup 3 aspek, yaitu:

a. Proses manufaktur/produksi sebuah perusahaan yang telah memanfaatkan tanda/label halal harus memperhatikan 4 hal berikut, yaitu:

1) Hewan yang dibersihkan adalah hewan yang dibunuh dengan cara disembelih.

2) Proses produksi tidak menggunakan bahan campuran yang terbuat dari barang haram maupun turunannya.

3) Menggunakan air mutlak/air bersih yang mengalir untuk membersihkan bahan.

4) Proses produksinya tidak boleh bercampur ataupun mendekati barang najis/haram.

b. Bahan mentah produk merupakan bahan mentah yang dipakai dalam proses produksi berupa bahan mentah (setengah jadi/bahan jadi). Sementara, bahan tambahan produk merupakan bahan yang tidak dipakai sebaai bahan baku produk yang hanya ditambahkan ke dalam proses produksi.

c. Bahan pembantu/tambahan merupakan bahan yang tidak masuk dalam kriteria bahan utama yang berperan penting dalam mempercepat ataupun memperlambat proses produksi seperti proses rekayasa. Proses ini melibatkan transfer gen yang membawa sifat dari 1 spesies biologi ke spesies lain yang disebut rekayasa genetika. Hal ini bertujuan untuk menghasilkan produk pangan unggulan yang diperoleh dari jenis baru.

Keputusan Menteri Kesehatan Republik Indonesia Nomor 82/Menkes/SK/I/1996 tentang Pencantuman Tulisan Halal Pada Label Pangan dan Perumahan dalam Bentuk Keputusan Menkes RI Nomor 924/Menkes/ SK/VII/1996 beserta peraturan pelaksanaannya berupa Surat Keputusan Direktur Jenderal POM No. IIK. 00.06.3.00568 tentang tata cara pencantuman tulisan halal pada label Pangan yang antara lain berisikan 6 hal, yaitu:

1. Direktur Jenderal BPOM memberikan persetujuan pencantuman tulisan halal pada label.

2. Produk makanan harus terdaftar di Kemenkes RI. 
3. Melewati pemeriksaan dan penilaian oleh tim (Kemenkes, Kemenag, dan MUI) persetujuan pencantuman label halal baru bisa diberikan.

4. Komisi Fatwa MUI mengeluarkan fatwa dan memberikan sertifikat halal setelah tim penilai memberikan hasil penilaian.

5. Direktur Jenderal BPOM memberikan persetujuan iklusi halal sesuai sertifikasi halal MUI.

6. Masa berlaku persetujuan sesuai dengan sertifikat, yakni selama 2 tahun.

Undang-Undang Nomor 8 Tahun 1999 tentang Perlindungan Konsumen, yaitu:

Pasal 7 butir (b):

Pengelola usaha wajib memberitahu informasi yang akurat dan jujur tentang syarat dan jaminan barang/jasa

Pasal 8 ayat 1 butir (b):

Pengelola usaha tidak boleh memproduksi/memperjualbelikan

barang/jasa yang tidak memenuhi syarat produksi halal. Seperti yang tercantum dalam pernyataan halal pada labelnya.

PP No. 69 Tahun 1999 tentang Label dan Iklan Pangan

Pasal 10 Setiap orang yang melakukan produksi pangan/makanan dalam kemasan ke Indonesia untuk diperjualbelikan dan memberi pernyataan bahwa makanan tersebut halal untuk umat manusia bertanggung jawab kepada kebenaran pernyataan tersebut dan harus memiliki pernyataan/tulisan halal pada labelnya.

Pasal 11:

1) Untuk mendukung kebenaran pernyataan kehalalan sebagaimana dimaksud dalam Pasal 10 ayat (1), setiap orang yang memproduksi atau memasukkan pangan kemasan ke dalam wilayah Indonesia untuk diperdagangkan harus terlebih dahulu memeriksakan pangan tersebut pada lembaga inspeksi yang terakreditasi sesuai dengan ketentuan peraturan perundang-undangan yang berlaku.

2) Pemeriksaan sebagaimana dimaksud pada ayat (1) dilakukan berdasarkan pedoman dan tata cara yang ditetapkan oleh Menteri Agama dengan memperhatikan pertimbangan dan saran dari lembaga keagamaan yang memiliki kompetensi di bidang tersebut.

Pasal 59:

Pengawasan terhadap pelaksanaan ketentuan mengenai label dan iklan dilakukan oleh Menteri Kesehatan.

Pasal 60:

1) Dalam melaksanakan ketentuan sebagaimana dimaksud dalam Pasal 59, Menteri Kesehatan mengangkat seorang pejabat yang diberi tugas pemeriksaan. 
2) Penyidik sebagaimana dimaksud pada ayat (1) dipilih dan diangkat oleh Menteri Kesehatan berdasarkan keahlian tertentu yang dimiliki.

3) Pejabat Pemeriksa sebagaimana dimaksud pada ayat (1) diangkat dan diberhentikan oleh Menteri Kesehatan.

Penjelasan PP No. 69 Tahun 1999 pasal 11 ayat 1 menyebutkan bahwa pencantuman tulisan halal pada dasarnya bersifat sukarela. Menurut Sampurno (2001) sanksi atas pelanggaran ketentuan pelabelan dapat dikenakan:

Pidana penjara paling lama 3 (tiga) tahun dan atau denda paling banyak Rp. 360.000.000 untuk pelanggaran UU no. 7 Tahun 1999 pasal 34 ayat (1).

Pidana penjara paling lama 5 (lima) tahun atau denda paling banyak dua miliar rupiah karena melanggar Undang-Undang Nomor 8 Tahun 1999 pasal 8 ayat (1) huruf h.

Tindakan administratif terhadap pelanggaran PP No. 69 Tahun 1999 yang meliputi:

1) Peringatan tertulis.

2) Larangan mengedarkan sementara dan atau memerintahkan penarikan produk pangan dari peredaran. $\underline{\text { Al-Qur'an }}$

"Hai manusia, dari (makanan) yang halal dan baik yang terdapat di bumi." (Surat al-Baqarah [2]:168).

"Dan Allah menghalalkan bagi mereka segala yang baik-baik dan mengharamkan bagi mereka yang buruk." (Surat Al-A'raaf [7]:157).

"Wahai manusia! Makanlah dari (makanan) yang halal dan baik yang terdapat di bumi, dan janganlah kamu mengikuti langkah-langkah setan.. Sesungguhnya setan adalah musuhmu yang sebenarnya." (QS $2: 168)$.

"Barangsiapa yang tidak memutuskan menurut apa yang diturunkan Allah, maka mereka itulah orang-orang yang kafir" [AlMaidah/5:44].

$\underline{\text { Hadis }}$

Hadits yang merujuk sabda Nabi:

Artinya: Telah menceritakan kepada kami, Abu Nu'aim. Telah menceritakan kepada kami, Zakaria dari "Amir berkata: saya mendengar An-Nu'man bin Basyir mengatakan, saya mendengar Rasulullah SAW bersabda: "Yang halal sudah jelas, dan yang haram juga sudah jelas". Tetapi diantara keduanya ada perkara syubhat yang banyak orang tidak tahu. Barangsiapa yang menjauhi diri dari syubhat maka agama dan kehormatannya telah terpelihara dan 


\section{Vol. 2 No. 2 Bulan Oktober 2021 - Maret 2022}

barangsiapa yang mengerjakan syubhat, dia seperti sedang menggembalakan ternaknya di pinggir jurang dan khawatir akan jatuh ke jurang terbut. Ketahuilah bahwa setiap penguasa memiliki batasan dan ketahuilah batasan larangan Allah SWT di bumi-Nya dan apa-apa yang diharamkan-Nya. Ketahuilah bahwa di setiap tubuh ada segumpal darah (mudghah).

Sa'ad bi Abi Waqash berkata kepada Rasulullah SAW, "Ya Rasulullah, doakan aku agar menjadi hamba yang dijabah doanya oleh Allah SWT". Rasulullah SAW menjawab, "Hai Sa'ad, perbaiki makananmu (makan yang halal) pasti kamu akan menjadi hamba yang doanya selalu dijabah. Dan demi jiwaku yang ada di genggaman-Nya, jika seorang memakan yang haram maka selama 40 hari amalannya tidak akan diterima. Dan daging yang tumbuh dari kecurangan dan riba maka dia pantas mendapatkan neraka" (HR. At-Thabrani).

\section{Kesimpulan dan Saran}

\subsection{Kesimpulan}

Bahwasanya produk-produk halal selain memberikan kesehatan secara jasmani dan rohani produk halal memberikan peluang bisnis baru dibidang wisata kuliner secara syariah.Bahwa dengan adanya produkproduk syariah ditengah-tengah pariwisata memberikan rasa kenyamanan nterkhusus bagi umat Islam.Bahwa pangsa pasar yang ditawarkan menyeluruh bagi seluruh umat sehingga memberikan nuansa yang berbeda dari lainnya.

\subsection{Saran}

Diharapkan bagi penelitis selanjutnya dapt meneliti dengan data yang lebih akurat lagi yang menggambarkan dampak medan menajdi kota syar'i.

\section{DAFTAR PUSTAKA}

Abi Abdul Jabbar, Wisata Halal,Penjelasan Kemenpar Soal Penerapan Wisata Halal di Indonesia, 5 September 2019.

Chacha Andira Sari, Perilaku Berbelanja Online Di Kalangan Mahasiswi Antropologi Universitas Airlangga AntroUnairdotNet, Vol.IV/No.2/Juli 2015, hal 209

Istijabatul Aliyah, Pemahaman Konseptual Pasar Tradisional Di Perkotaan, Istijabatul Aliyah Cakra Wisata Vol 18 Jilid 2 Tahun 2017, h.2.

Kiki Joesyiana, Pengaruh Word Of Mouth Terhadap Keputusan Pembelian Konsumen Pada Media Online Shop Shopee Di Pekanbaru, Jurnal Valuta Vol. 4 No 1, April 2018 ISSN : 2502141971 (Survey pada Mahasiswa Semester VII Jurusan Pendidikan Akuntansi Fakultas Keguruan dan Ilmu Pendidikan Universitas Islam Riau) Akademi Sekretari dan Manajemen Persada Bunda, h.74 
Medan,Sumutpos.Com, MUI Medan Telah Keluarkan 767 Sertifikat Halal - Sumut Possumutpos.co , 2019/07/27, muimedan-telah-keluarka

http://repository.uma.ac.id/bitstrea $\mathrm{m} / 123456789 / 752 / 5 / 128320039$ fil e5.pdf, h.7

Shandy Widjoyo Putro; Hatane Semuel, MS; Ritzky Karina M.R. Brahmana; Pengaruh Kualitas Layanan Dan Kualitas Produk Terhadap Kepuasan Pelanggan Dan Loyalitas Konsumen Restoran Happy Garden Surabaya Jurusan Manajemen Pemasaran, Universitas Kristen PetraJl. Siwalankerto 121-131, Surabaya, Jurnal Manajemen Pemasaran Vol.2, No. 1, (2014) 1-93

Siti Muzdalifah, Sukidin Pudjo Suharso Karakteristik Pedagang Tradisional Di Pasar Kepatihan Kabupaten Jember Program Studi Pendidikan Ekonomi, Fakultas Keguruan dan Ilmu Pendidikan Universitas Jember Jurnal Pendidikan Ekonomi: Jurnal Ilmiah Ilmu Pendidikan, Ilmu Ekonomi, dan Ilmu Sosial ISSN 1907-9990 | E-ISSN 2548-7175 | Volume 13 Nomor 1 (2019),h.98. 